\title{
Occurrence of gastrointestinal protozoans in cats from Londrina, Paraná, Brazil
}

\section{Ocorrência de protozoários gastrointestinais em gatos de Londrina, Paraná, Brasil}

\author{
Keila Jimenez Torrico ${ }^{1}$; Nelson Jessé Rodrigues dos Santos ${ }^{2}$; Hugo Luca Abate ${ }^{2}$; \\ Felippe Danyel Cardoso Martins'; ${ }^{2}$ Luiz Daniel de Barros ${ }^{3}$; Mércia Seixas²; Thais \\ Agostinho Martins'; ; João Luis Garcia ${ }^{3}$; Odilon Vidotto ${ }^{3 *}$
}

\begin{abstract}
Protozoans are widely distributed, and several species may parasitize the digestive tracts of cats (Felis catus), and can be transmitted to humans. The present study aimed to evaluate the species and occurrence of gastrointestinal protozoans in cats in the city of Londrina, Paraná, Brazil. A total of 206 cat fecal samples were tested, of which 141 were from shelter animals, and 65 were from pets owned by local people. Samples were processed by parasitological techniques. Coproparasitological techniques (Willis, Faust and Ziehl-Neelsen) were performed for detection of protozoan parasites. Subsequently, all samples were processed by PCR protocols specific to Toxoplasma gondii, Giardia spp., and Cryptosporidium spp. PCR products from positive samples were selected for sequencing. No samples were found to be positive for Cryptosporidium spp. using the Ziehl-Neelsen technique. Using specific PCR protocols, $1 / 206(0.48 \%)$ samples tested positive for Cryptosporidium spp. After purification, this one positive sample was sequenced, and it demonstrated a $100 \%$ identity match to Cryptosporidium muris. Using specific PCR protocols, 13/206 (9.22\%) cat fecal samples tested, including 2/65 (3.08\%) pet cat fecal samples, were positive for $T$. gondii. PCR analysis revealed that 37/206 (17.96\%) of cat fecal samples were positive for Giardia spp., including 27/141 (19.15\%) of shelter cat fecal samples, and 10/65 $(15.38 \%)$ pet cat fecal samples $(\mathrm{p}=0.5124)$. When sequenced, these positive samples showed a $100 \%$ identity match with Giardia duodenalis. This study demonstrated that infections with Cryptosporidium spp., Toxoplasma gondii, and Giardia duodenalis are present in the population of both pet cats and shelter cats in the city of Londrina. This poses a risk to public health, because these parasites have a high zoonotic potential.
\end{abstract}

Key words: PCR. Feline. Shelter. Cryptosporidium muris. Toxoplasma gondii. Giardia duodenalis.

\section{Resumo}

Os protozoários são amplamente distribuídos, e várias espécies podem parasitar o trato digestivo de gatos (Felis catus) e podem ser transmitidas para humanos. O presente estudo teve como objetivo avaliar as espécies e a ocorrência de protozoários gastrintestinais em gatos na cidade de Londrina, Paraná, Brasil.

\footnotetext{
${ }^{1}$ Discente de Mestrado, Programa de Pós-Graduação em Ciência Animal, Universidade Estadual de Londrina, UEL, Londrina, PR, Brasil. E-mail: keilajt@hotmail.com

2 Discentes de Doutorado, Programa de Pós-Graduação em Ciência Animal, UEL, Londrina, PR, Brasil. E-mail: nelson. rodriguesmv@gmail.com; hugoabate@gmail.com; felippemartins@hotmail.com; mercia_seixas@yahoo.com.br; thaismedvet620@gmail.com

3 Profs. Drs., Departamento de Medicina Veterinária, UEL, Londrina, PR, Brasil. E-mail: luizdanielbarros@gmail.com; joaoluisgarcia10@gmail.com; vidotto@uel.br

* Author for correspondence
} 
Um total de 206 amostras de fezes de gato foram testadas, das quais 141 eram de animais de abrigo, e 65 eram de animais de propriedade da população local. As amostras foram processadas por técnicas parasitológicas. Willis e esfregaços fecais foram confeccionados e corados pela técnica de Ziehl-Neelsen modificada para detecção de oocistos de Cryptosporidium spp. Posteriormente, todas as amostras foram processadas por protocolos de PCR específicos para Toxoplasma gondii, Giardia spp. e Cryptosporidium spp. Os produtos de PCR de amostras positivas foram selecionados para sequenciamento. Nenhuma amostra foi considerada positiva para Cryptosporidium spp. usando a técnica de Ziehl-Neelsen. Utilizando protocolos específicos de PCR, 1/206 (0,48\%) amostras apresentaram resultados positivos para Cryptosporidium spp. Após a purificação, essa amostra positiva foi sequenciada e demonstrou $100 \%$ de equivalência de identidade com Cryptosporidium muris. Utilizando protocolos específicos de PCR, 13/206 (9,22\%) amostras fecais de gatos testadas, incluindo 2/65 (3,08\%) amostras fecais de gatos de estimação, foram positivas para T. gondii. A análise de PCR revelou que 37/206 (17,96\%) das amostras de fezes de gatos foram positivas para Giardia spp., Incluindo 27/141 (19,15\%) de amostras fecais de gatos de abrigo, e 10/65 (15,38\%) amostras fecais de gatos de estimação ( $p=0,5124)$. Quando sequenciadas, essas amostras positivas apresentaram $100 \%$ de equivalência de identidade com Giardia duodenalis. Este estudo demonstrou que as infecções por Cryptosporidium spp., Toxoplasma gondii e Giardia duodenalis estão presentes na população de gatos de estimação e gatos de abrigo na cidade de Londrina. Isso representa um risco para a saúde pública, pois estes parasitas têm um alto potencial zoonótico.

Palavras-chave: PCR. Felinos. Abrigo. Cryptosporidium muris. Toxoplasma gondii. Giardia duodenalis.

\section{Introduction}

Pets, especially dogs and cats, are beneficial to people and society, as they contribute to the physical, social, and emotional development of children, and the well-being of their owners. However, close contact between animals and humans may involuntarily represent a risk to human health. Therefore, adequate control of parasites is essential to reduce environmental contamination with infectious forms of parasites, and, consequently, minimize infection risks for humans and animals (Dantas-Torres \& Otranto, 2014; Robertson, Irwin, Lymbery, \& Thompson, 2000).

Cryptosporidium is a genus of protozoans, and its transmission occurs by the oral fecal route, with outbreaks reported around the world (Kourenti, Karanis, \& Smith, 2007)with the UK accounting for $24 \%$ of outbreaks, worldwide. Giardia duodenalis and Cryptosporidium parvum account for the majority of outbreaks $(132 ; 40.6 \%$ and 165 ; $50.8 \%$, respectively. Currently, 29 Cryptosporidium species have been described, and 17 of these are considered to have zoonotic potential. However, the Cryptosporidium species can only be differentiated using molecular techniques (Zahedi, Paparini, Jian, Robertson, \& Ryan, 2016). The worldwide prevalence of Cryptosporidium species in cats has been described as ranging from 0.6 to $15.4 \%$ (Bowman \& Lucio-Forster, 2010). Regarding Cryptosporidium species in cats, C. felis has been the most frequently identified, with $C$. muris found at a lower frequency, although both have zoonotic potential (Santin, Trout, Vecino, Dubey, \& Fayer, 2006; Yang, Ying, Monis, \& Ryan, 2015).

Toxoplasma gondii is a protozoan parasite that can infect a wide range of animal species, including humans. Felids are important in the life cycle of $T$. gondii, since they are definitive hosts, and therefore able to shed oocysts through feces, contaminating the environment (Hill \& Dubey, 2002). The importance of toxoplasmosis in public health lies mainly in outbreaks of toxoplasmosis, including ocular toxoplasmosis, and the severity of congenital toxoplasmosis infection and its effects on fetuses (Hill \& Dubey, 2002; Nissen et al., 2017). However, the pathogenesis of the disease is dependent on the infectious dose, the strain, and the immunologic host status (Ajzenberg, 2011). Reports of T. gondii 
in cat feces from Brazil are scarce. Nevertheless, it is well known that $T$. gondii isolates from Brazil show higher diversity when compared with isolates from the northern hemisphere (Dubey et al., 2004; Pena, Soares, Amaku, Dubey, \& Gennari, 2006; Shwab et al., 2014).

Giardia duodenalis is one of the most common parasitic infections in dogs and cats worldwide, and infected animals may show moderate to severe clinical illness or become asymptomatic (Ballweber, Xiao, Bowman, Kahn, \& Cama, 2010). According with molecular analysis, there are seven genotype groups of $G$. duodenalis, and although cats are primarily infected with Assemblage F, they can carry Assemblage A and B, which have zoonotic potential, making cats as important source of infection for humans (Xiao \& Fayer, 2008).

Many studies using shelter cats in several countries found that the cats were shedding a large number of protozoan species, such as Isospora spp., Giardia spp., Sarcocystis spp., and different helminths species (Bissett et al., 2009; Christie, Dubey, \& Pappas, 1976; Gracenea, Gómez, \& Torres, 2012; Guterbock \& Levine, 1977; LucioForster \& Bowman, 2011; Robben et al., 2004; Sabshin et al., 2012).

This study aimed to detect gastrointestinal protozoans in cats from two distinct habitats in Brazil.

\section{Material and Methods}

\section{Local sampling and cats}

Two hundred and six stool samples from cats were collected between September 2012 and May 2013 in Londrina city, Paraná state, Brazil, including 141 from cats in shelters (referred to hereafter as 'shelter cats'), and 65 from local households (referred to hereafter as 'pet cats').

Samples were collected immediately after cats defecated, stored in appropriately labelled containers in thermal boxes and processed in the Laboratory of Veterinary Parasitology of Londrina State University. All animal procedures were approved by the Ethics Committee for Animal Use of Londrina State University (CEUA n ${ }^{\circ} n^{\circ} 17396.2012 .48$ ), and by the cat owners in an authorization form.

\section{Parasitological exams}

Fecal samples were processed using the techniques of Willis, Faust, and Ziehl-Neelsen, with modifications for the detection of cysts and protozoan oocysts (Faust et al., 1939; Ortolani, 2000; Willis, 1921). The parts of the fecal samples not used for this analysis were stored at $-20{ }^{\circ} \mathrm{C}$ for DNA extraction and PCR.

\section{$D N A$ extraction and $P C R$}

DNA was extracted from all fecal samples using a commercial kit (Macherey-Nagel NucleoSpin Tissue Kit, Germany), according to the manufacturer's instructions.

PCRs for T. gondii were performed by amplification of a specific fragment of 529 bp that repeats 200 to 300 times, according to previously described methodology (Homan, Vercammen, De Braekeleer, \& Verschueren, 2000). For Cryptosporidium spp., a nested PCR that amplifies an 18S rRNA gene fragment, was used, as previously described (Xiao et al., 1999). For Giardia spp., a nested-PCR targeting an 18S rRNA gene fragment was performed, as previously described (Appelbee, Frederick, Heitman, \& Olson, 2003; Hopkins et al., 1997).

PCR products were submitted to a $1.5 \%$ agarose gel electrophoresis, stained with $\mathrm{SYBR}^{\circledR}$ Safe (DNA Gel Stain; Invitrogen, Brazil), and visualized under UV light. A 100 bp DNA ladder (100 bp DNA Ladder, Invitrogen, Brazil), and positive and negative controls were included in all agarose gels. 


\section{PCR-RFLP}

In fecal samples in which Toxoplasma-like oocysts were observed and confirmed by PCR, DNA samples were used to perform genetic characterization by means of PCR-RFLP using 11 genetic markers (SAG1, SAG2, alt. SAG2, SAG3, BTUB, GRA6, c22-8, c29-2, L358, PK1 and APICO) according to previously described methodology ( $\mathrm{Su}$, Shwab, Zhou, Zhu, \& Dubey, 2010; Su, Zhang, \& Dubey, 2006). DNA from reference samples (GT1, PTG, CTG, TgCgCa1, MAS, TgCatBr5, TgCatBr64, and TgRsCr1) and ultrapure water were included in all reactions, and used as positive and negative controls, respectively. The obtained results were compared, identified, and classified in accordance with the genotypes present in ToxoDB at http://toxodb.org/toxo. Phylogenetic analysis comparing the isolates with the reference strains was performed using the Split Tree software version 4.13 (Huson \& Bryant, 2006).

\section{Sequencing}

Samples that were PCR-positive for Cryptosporidium spp. and Giardia spp. were purified using PureLink Quick Gel Extraction Kit (Invitrogen Carlsbad, California, USA), following the manufacturer's recommendations. Sequencing was performed using Big Dye terminator v3.1 Cycle Sequencing Kit (Applied Biosystems, Foster City, CA, USA), and an ABI300 genetic analyzer sequencer (Applied Biosystems, Foster city, CA, USA).

The nucleotide sequences obtained were compared to standard sequences deposited in GenBank using the BLAST sequence analysis tool.

\section{Statistical analysis}

To analyze the results, the Wilson score interval was used to estimate confidence intervals, and Yates corrected Chi-square test was used to measure statistical association. All statistical analyses were performed with the Epitools software and epidemiological calculators (Sergeant, 2017).

\section{Results}

Regarding the copro-parasitological exams, $36 / 206$ (17.48\%) of the samples were positive for any of the protozoans (Table 1). We observed mixed infections in only one $(0.48 \%)$ cat, and the protozoans observed were Toxoplasma-like and Cystoisospora spp.

Regarding the PCR analysis, $15 / 206$ (7.28\%; 95\% CI: 4.46 - 11.67) samples were positive for $T$. gondii, including $13 / 141(9.22 \%$; $95 \% \mathrm{CI}$ : 5.47 - 15.14) samples from shelter cats, and $2 / 65$ (3.08\%; 95\% CI: 0.85 - 10.54) samples from pet cats $(p=0.115)$. When comparing the samples that were positive for Toxoplasma-like in the coproparasitological analysis with samples that were positive for $T$. gondii in the PCR analysis, only one sample tested positive using both techniques, which was the only sample genotyped (Table 2). According to ToxoDB, the sample was characterized as genotype \#65, an atypical strain not related with clonal strains (Figure 1). It was not possible to genotype the other samples because they did not amplify in all markers, probably due to low DNA concentrations. 


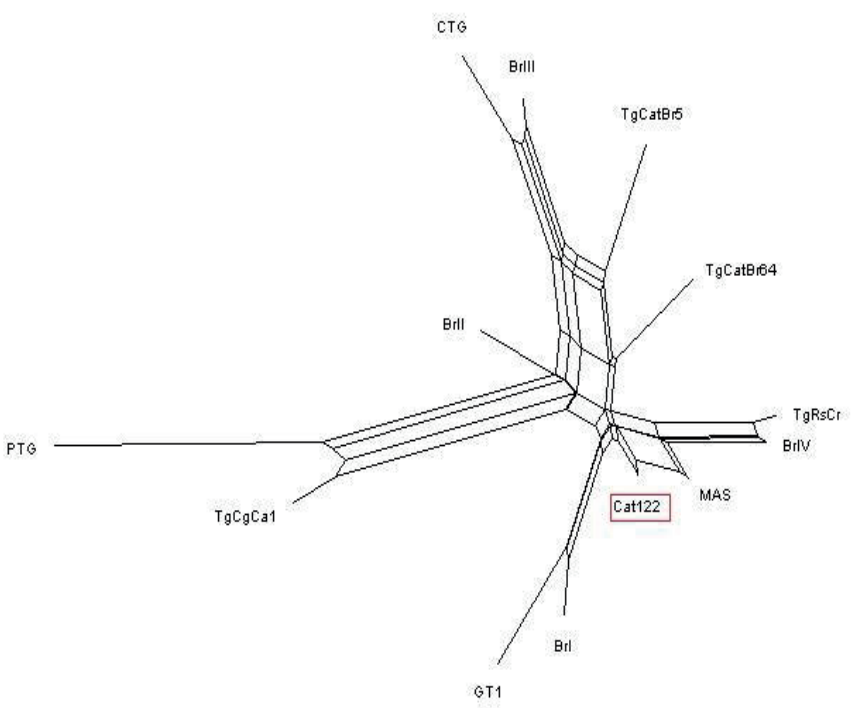

Figure 1. Phylogenetic tree of the Toxoplasma gondii isolate obtained (red box) from cats from Londrina, Paraná state, Brazil compared with the reference strains GT1, PTG, CTG, TgCgCa1, MAS, TgCatBr5,TgCatBr64, TgRsCr1, BrI, BrII, BrIII, BrIV.

Regarding Cryptosporidium, all of the 206 fecal samples analyzed using the Ziehl-Neelsen method were negative. However, one sample (from a shelter cat, $0.48 \%$; 95\% CI: $0.01-2.70$ ) was positive when tested with the $18 \mathrm{~S}$ rRNA PCR. The sequencing result showed $100 \%$ identity match with Cryptosporidium muris (access no. KY483984). Regarding Giardia duodenalis, 37/206 (17.96\%;
95\% CI: 13.32 - 23.77) samples tested positive using the nested PCR, which included 27/141 (19.15\%; 95\% CI: 13.51 - 26.43) samples from shelter cats, and 10/65 (15.38\%; 95\% CI: $8.58-$ 26.06) samples from pet cats $(\mathrm{p}=0.5124)$. Four samples were randomly selected and sequenced, and all of these showed $100 \%$ identity match with Giardia duodenalis (access no. KX384156).

Table 1

Frequency of intestinal protozoans observed in different coproparasitological exams (Willis; Faust and ZiehlNeelsen) of shelter and pet cats from Londrina, Brazil

\begin{tabular}{lcccccc}
\hline & \multicolumn{2}{c}{ Shelter $(\mathrm{n}=141)$} & \multicolumn{2}{c}{ Pet $(\mathrm{n}=65)$} & \multicolumn{2}{c}{ Total $(\mathrm{n}=206)$} \\
\hline & Positive (\%) & $95 \%$ IC & Positive (\%) & $95 \%$ IC & Positive (\%) & $95 \%$ IC \\
\hline Cystoisospora spp. & $11(7.80)$ & $4.41-13.43$ & $9(13.85)$ & $7.46-24.27$ & $20(9.71)$ & $6.37-14.52$ \\
Giardia spp. & $13(9.93)$ & $5.47-15.14$ & $0(-)$ & $0.01-5.58$ & $13(6.31)$ & $3.72-10.50$ \\
Sarcocystis spp. & $0(-)$ & $0.01-2.65$ & $1(1.54)$ & $0.27-8.21$ & $1(0.49)$ & $0.01-2.70$ \\
Toxoplasma-like & $3(2.13)$ & $0.73-6.07$ & $0(-)$ & $0.00-5.58$ & $3(1.46)$ & $0.50-4.19$ \\
Cryptosporidium spp. & $0(-)$ & $0.01-2.65$ & $0(-)$ & $0.01-5.58$ & $0(-)$ & $0.00-1.83$ \\
\hline
\end{tabular}


Table 2

PCR-RFLP genotypic profiles from Toxoplasma gondii obtained from cats from Londrina, Paraná state, Brazil

\begin{tabular}{|c|c|c|c|c|c|c|c|c|c|c|c|c|c|}
\hline \multirow{2}{*}{\multicolumn{2}{|c|}{ Isolate }} & \multicolumn{11}{|c|}{ Markers } & \multirow{2}{*}{$\begin{array}{c}\text { Genotype } \\
\text { ToxoDB }\end{array}$} \\
\hline & & \multirow{2}{*}{$\frac{\text { SAG1 }}{\text { I }}$} & \multirow{2}{*}{$\frac{\mathrm{SAG} 2}{\mathrm{I}}$} & \multirow{2}{*}{$\begin{array}{c}\begin{array}{c}\text { alt. } \\
\text { SAG2 }\end{array} \\
\text { I }\end{array}$} & \multirow{2}{*}{$\frac{\text { SAG3 }}{\mathrm{I}}$} & \multirow{2}{*}{$\frac{\text { BTUB }}{\mathrm{I}}$} & \multirow{2}{*}{$\frac{\text { GRA6 }}{\text { I }}$} & \multirow{2}{*}{$\frac{\mathrm{c} 22-8}{\mathrm{I}}$} & \multirow{2}{*}{$\frac{c 29-2}{I}$} & \multirow{2}{*}{$\frac{\mathrm{L} 358}{\mathrm{I}}$} & \multirow{2}{*}{$\begin{array}{c}\text { PK1 } \\
\text { I }\end{array}$} & \multirow{2}{*}{$\frac{\text { Apico }}{\mathrm{I}}$} & \\
\hline GT1 & Reference & & & & & & & & & & & & $\# 10$ \\
\hline PTG & Reference & II/III & II & II & II & II & II & II & II & II & II & II & $\# 1$ \\
\hline CTG & Reference & II/III & III & III & III & III & III & III & III & III & III & III & $\# 2$ \\
\hline $\mathrm{TgCgCa} 1$ & Reference & I & II & II & III & II & II & II & $\mathrm{u}-1$ & I & $\mathrm{u}-2$ & I & $\# 66$ \\
\hline MAS & Reference & $\mathrm{u}-1$ & I & II & III & III & III & $\mathrm{u}-1$ & I & I & III & I & $\# 17$ \\
\hline TgCatBr5 & Reference & I & III & III & III & III & III & I & I & I & $\mathrm{u}-1$ & I & $\# 19$ \\
\hline TgCatBr64 & Reference & I & I & $\mathrm{u}-1$ & III & III & III & $\mathrm{u}-1$ & I & III & III & I & $\# 111$ \\
\hline TgRsCr1 & Reference & $\mathrm{u}-1$ & I & II & III & I & III & $\mathrm{u}-2$ & I & I & III & I & \#52 \\
\hline Cat122 & This study & I & I & II & III & III & III & $\mathrm{u}-1$ & I & I & III & I & $\# 65$ \\
\hline
\end{tabular}

\section{Discussion}

Shelter cats are known to have a higher seroprevalence of $T$. gondii when compared to pet cats (Bolais et al., 2017), although, in our dataset, there were no statistically significant differences between $T$. gondii infection rates of shelter cats and pet cats. This result may have been influenced by sampling, environmental, and behavioral factors.

Depending on the environments inhabited by cats, which may allow exploration of backyards and surrounding areas, shelter cats and pet cats can prey on infected birds and rodents. In Londrina, 22.3\% of eared doves (Zenaida auriculata) were found to be seropositive for T. gondii (Barros et al., 2014), while $8.8 \%$ of rodents tested positive for $T$. gondii antibodies (Ruffolo et al., 2016), indicating that this parasite can infect animals that can be naturally preyed on by cats.

Most cats that hunt frequently are re-exposed to T. gondii, maintaining their immunity against the parasite. This may explain why, in a previous study, T. gondii oocysts were detected in less than $1 \%$ of cat fecal samples (Dubey, 2010). Considering this, our results were unexpected, since we found that $7.28 \%$ of the cat fecal samples were PCR-positive for $T$. gondii.
Cats from Costa Rica also showed high shedding rates for T. gondii, with $23.2 \%$ of cats testing positive for T. gondii (Ruiz \& Frenkel, 1980). These results contrast with another study that analyzed 237 cat fecal samples from 15 municipalities of São Paulo, Brazil, and identified only three positive samples (Pena et al., 2006). An environment with high contamination of $T$. gondii oocysts is of extreme importance in the maintenance of the protozoan, as this environment serves as a source of infection for both humans and animals (Moura, Osaki, Zulpo, \& Marana, 2007).

Genotyping by means of PCR-RFLP found one T. gondii genotype classified as ToxoDB\#65. This genotype has been previously described in cats in Brazil (Pena, Gennari, Dubey, \& Su, 2008; Pena et al., 2006). Additionally, a genotype of T. gondii found in chickens, humans, eared doves, and pigs in Brazil (Barros et al., 2014; Dubey et al., 2008; Ferreira et al., 2011; Samico-Fernandes et al., 2015) was characterized as atypical, which is consistent with a previous study that found a high genetic diversity in T. gondii isolates from South America (Shwab et al., 2014). The fact that the same genotype was recorded in different animal species indicates that T. gondii is widely spread around Brazil, infecting different animal species from different regions. 
The frequency of Cryptosporidium in cats living in shelters has been described as $100 \%$ in the United States, and 13\% in Bogotá, Colombia (Fayer, Santin, Trout, \& Dubey, 2006; Santin et al., 2006). This is in contrast to our results, as we found low prevalence of Cryptosporidium (1/206 samples), and these previous studies report a much higher frequency. In Brazil, in a study conducted on shelter cats from Nova Iguaçu, nine of 30 cats tested positive for Cryptosporidium spp. by microscopic examination. Using RFLP analysis, three of these nine Cryptosporidium spp. positive samples were characterized as $C$. felis, a zoonotic species that is commonly found in cats (Huber, Silva, Bomfim, Teixeira, \& Bello, 2007).

In the present study, we found that one sample from a shelter cat contained $C$. muris. Since this species is known to infect rodents, and considering that rodents are a prey species for cats, it is not abnormal to find this species of Cryptosporidium in cats. C. muris has a zoonotic potential, and was described as a cause of chronic infection in healthy humans (Chappell et al., 2015).

Infection by Cystoisospora spp. in shelter cats was described in the Americas, Europe, and Oceania, with infection rates ranging from 1\% to $21 \%$ (Bissett et al., 2009; Christie et al., 1976; Lucio-Forster \& Bowman, 2011; Robben et al., 2004). Few studies have been conducted on this parasite in cats in Brazil. In one study, using shelter animals from Rio de Janeiro, 2.2\% (2/91) of cats tested positive for Cystoisospora spp. (Pereira et al., 2017). This is in contrast with our findings, as we found higher rates of Cystoisospora spp. in shelter cats and pet cats.

Another intestinal protozoan commonly found in cats is Giardia spp., and some assemblages of Giardia have zoonotic potential. It has been shown that shelter cats are disseminators of this protozoan in the environment, with shedding rates ranging from $1 \%$ to $28 \%$ of cats (Bissett et al., 2009; Bowman \&
Lucio-Forster, 2010; Gracenea et al., 2012; LucioForster \& Bowman, 2011; Robben et al., 2004; Sabshin et al., 2012; Yang et al., 2015). Our results emphasize the potential risk of cats spreading Giardia duodenalis cysts in the environment. Cats may, as such, play a role as a source of infection both for humans and other animals. No statistical difference was observed between pet cats and shelter cats. It is likely that the shelter environment does not result in a high prevalence of Giardia when compared with the environment of pet cats, and so both populations could be equally exposed (Bissett et al., 2009).

One neglected protozoan of the domestic cats is Sarcocystis spp. Different studies have found this protozoan in shelter cats in the United States (Christie et al., 1976; Lucio-Forster \& Bowman, 2011). Similar to our study, Sarcocystis spp. was found in pet cats from Rio de Janeiro, with $0.8 \%(1 / 131)$ of cats testing positive (Serra, Uchôa, \& Coimbra, 2003). In another study, conducted in a veterinary hospital in São Paulo city, 1.4\% (7/502) of cats were found to be shedding this parasite (Gennari, Ferreira, Pena, Labruna, \& Azevedo, 2016).

\section{Conclusions}

In conclusion, cats in the urban area of Londrina were found to shed the following protozoans: Cryptosporidium muris, T. gondii, and Giardia duodenalis. T. gondii was found more frequently in shelter cats than in pet cats, although this was not statistically significant. Based on zoonotic importance, the situation in shelters regarding parasite shedding appears to be of greater importance than that of pet cats owne by local families.

To the authors' knowledge, this is the first study on Giardia duodenalis, Toxoplasma gondii, and Cryptosporidium muris in shelter cats in Brazil. 


\section{Acknowledgments}

We would like to thank the Conselho Nacional de Desenvolvimento Científico e Tecnológico (CNPq), and Coordenação de Aperfeiçoamento de Pessoal de Nivel Superior (CAPES) for financial support.

\section{Competing Interests}

All the authors declare that they have no competing interests.

\section{References}

Ajzenberg, D. (2011). Unresolved questions about the most successful known parasite. Expert Review of Anti-Infective Therapy, 9(2), 169-171. doi: 10.1586/ eri.10.169

Appelbee, A. J., Frederick, L. M., Heitman, T. L., \& Olson, M. E. (2003). Prevalence and genotyping of Giardia duodenalis from beef calves in Alberta, Canada. Veterinary Parasitology, 112, 289-294. doi: 10.1016/S0304-4017(02)00422-3

Ballweber, L. R., Xiao, L., Bowman, D. D., Kahn, G., \& Cama, V. A. (2010). Giardiasis in dogs and cats: update on epidemiology and public health significance. Trends in Parasitology, 26(4), 180-189. doi: $10.1016 / j . p t .2010 .02 .005$

Barros, L. D. de, Taroda, A., Zulpo, D. L., Cunha, I. A. L. da, Sammi, A. S., Cardim, S. T.,... Garcia, J. L. (2014). Genetic characterization of Toxoplasma gondii isolates from eared doves (Zenaida auriculata) in Brazil. Revista Brasileira de Parasitologia Veterinária, 23(4), 443-448. doi: 10.1590/S198429612014073

Bissett, S. A., Stone, M. L., Malik, R., Norris, J. M., O’Brien, C., Mansfield, C. S.,... Gookin, J. L. (2009). Observed occurrence of Tritrichomonas foetus and other enteric parasites in Australian cattery and shelter cats. Journal of Feline Medicine and Surgery, 11(10), 803-807. doi: 10.1016/j.jfms.2009.02.001

Bolais, P. F., Vignoles, P., Pereira, P. F., Keim, R., Aroussi, A., Ismail, K.,... Mercier, A. (2017). Toxoplasma gondii survey in cats from two environments of the city of Rio de Janeiro, Brazil by Modified Agglutination Test on sera and filter-paper. Parasites \& Vectors, 10(1), 88. doi: 10.1186/s13071-0172017-8

Bowman, D. D., \& Lucio-Forster, A. (2010).
Cryptosporidiosis and giardiasis in dogs and cats: Veterinary and public health importance. Experimental Parasitology, 124(1), 121-127. doi: 10.1016/j.exppara.2009.01.003

Chappell, C. L., Okhuysen, P. C., Langer-Curry, R. C., Lupo, P. J., Widmer, G., \& Tzipori, S. (2015). Cryptosporidium muris: infectivity and illness in healthy adult volunteers. The American Journal of Tropical Medicine and Hygiene, 92(1), 50-55. doi: doi.org/10.4269/ajtmh.14-0525

Christie, E., Dubey, J. P., \& Pappas, P. W. (1976). Prevalence of Sarcocystis infection and other intestinal parasitisms in cats from a humane shelter in Ohio. Journal of the American Veterinary Medical Association, 168(5), 421-422.

Dantas-Torres, F., \& Otranto, D. (2014). Dogs, cats, parasites, and humans in Brazil: opening the black box. Parasites \& Vectors, 7(22), 1-25. doi: 10.1186/1756-3305-7-22

Dubey, J. P. (2010). Toxoplasmosis of animals and dumans (2nd ed.). Boca Raton: CRC Press.

Dubey, J. P., Navarro, I. T., Sreekumar, C., Dahl, E., Freire, R. L., Kawabata, H. H.,... Lehmann, T. (2004). Toxoplasma gondii infections in cats from Paraná, Brazil: seroprevalence, tissue distribution, and biologic and genetic characterization of isolates. The Journal of Parasitology, 90(4), 721-726. doi: $10.1645 / \mathrm{GE}-382 \mathrm{R}$

Dubey, J. P., Velmurugan, G. V., Chockalingam, A., Pena, H. F. J., Oliveira, L. N. de., Leifer, C. A.,... Su, C. (2008). Genetic diversity of Toxoplasma gondii isolates from chickens from Brazil. Veterinary Parasitology, 157(3-4), 299-305. doi: 10.1016/j. vetpar.2008.07.036

Faust, E. C., Sawitz, W., Tobie, J., Odom, V., Peres, C., \& Lincicome, D. R. (1939). Comparative efficiency of various technics for the diagnosis of protozoa and helminths in feces. The Journal of Parasitology, 25(3), 241-262. doi: 10.2307/3272508

Fayer, R., Santin, M., Trout, J. M., \& Dubey, J. P. (2006). Detection of Cryptosporidium felis and Giardia duodenalis Assemblage $\mathrm{F}$ in a cat colony. Veterinary Parasitology, 140(1-2), 44-53. doi: 10.1016/j. vetpar.2006.03.005

Ferreira, I. M. R., Vidal, J. E., de Mattos, C. D. C. B., de Mattos, L. C., Qu, D., Su, C., \& Pereira-Chioccola, V. L. (2011). Toxoplasma gondii isolates: multilocus RFLP-PCR genotyping from human patients in Sao Paulo State, Brazil identified distinct genotypes. Experimental Parasitology, 129(2), 190-195. doi: 
doi.org/10.1016/j.exppara.2011.06.002

Gennari, S. M., Ferreira, J. I. G. da S., Pena, H. F. de J., Labruna, M. B., \& Azevedo, S. D. S. (2016). Frequency of gastrointestinal parasites in cats seen at the University of Sao Paulo Veterinary Hospital, Brazil. Revista Brasileira de Parasitologia Veterinaria, 25(4), 423-428. doi: 10.1590/S198429612016082

Gracenea, M., Gómez, M. S., \& Torres, J. (2012). Prevalence of intestinal parasites in shelter dogs and cats in the metropolitan area of Barcelona (Spain). Acta Parasitologica, 54(1), 73-77. doi: 10.2478/ s11686-009-0005-7

Guterbock, W. M., \& Levine, N. D. (1977). Coccidia and intestinal nematodes of East Central Illinois cats. Journal of the American Veterinary Medical Association, 170(12), 1411-1423.

Hill, D., \& Dubey, J. P. (2002). Toxoplasma gondii: transmission, diagnosis and prevention. Clinical Microbiology and Infection, 8(10), 634-640.

Homan, W. L., Vercammen, M., De Braekeleer, J., \& Verschueren, H. (2000). Identification of a 200to 300 -fold repetitive 529 bp DNA fragment in Toxoplasma gondii, and its use for diagnostic and quantitative PCR. International Journal for Parasitology, 30(1), 69-75.

Hopkins, R. M., Meloni, B. P., Groth, D. M., Wetherall, J. D., Reynoldson, J. A., \& Thompson, R. C. A. (1997). Ribosomal RNA sequencing reveals differences between the genotypes of giardia isolates recovered from humans and dogs Living in the Same Locality. The Journal of Parasitology, 83(1), 44-51. doi: $10.2307 / 3284315$

Huber, F., Silva, S. da., Bomfim, T. C. B., Teixeira, K. R. S., \& Bello, A. R. (2007). Genotypic characterization and phylogenetic analysis of Cryptosporidium sp. from domestic animals in Brazil. Veterinary Parasitology, 150(1-2), 65-74. doi: 10.1016/j. vetpar.2007.08.018

Huson, D. H., \& Bryant, D. (2006). Application of phylogenetic networks in evolutionary studies. Molecular Biology and Evolution, 23(2), 254-267. doi: $10.1093 / \mathrm{molbev} / \mathrm{msj030}$

Kourenti, C., Karanis, P., \& Smith, H. (2007). Waterborne transmission of protozoan parasites: A worldwide review of outbreaks and lessons learnt. Journal of Water and Health, 5(1), 1-38. doi: 10.2166/ wh.2006.002

Lucio-Forster, A., \& Bowman, D. D. (2011). Prevalence of fecal-borne parasites detected by centrifugal flotation in feline samples from two shelters in upstate New York. Journal of Feline Medicine and Surgery, 13(4), 300-303. doi: 10.1016/j.jfms.2010.12.013

Moura, A. B. de, Osaki, S. C., Zulpo, D. L., \& Marana, E. R. M. (2007). Occurrence of anti-Toxoplasma gondii antibodies in swine and ovine slaughtered at municipality of Guarapuava in the State of Parana, Brazil. Revista Brasileira de Parasitologia Veterinaria, 16(1), 54-56.

Nissen, J., Jokelainen, P., Stensvold, C. R., Trevisan, C., Fuchs, J., Burgdorf, K. S.,... Pires, S. M. (2017). The disease burden of congenital toxoplasmosis in Denmark, 2014. PloS One, 12(5), e0178282. doi: 10.1371/journal.pone.0178282

Ortolani, E. L. (2000). Brazilian journal of veterinary parasitology : Órgão Oficial do Colégio Brasileiro de Parasitologia Veterinária. Revista Brasileira de Parasitologia Veterinária, 9(1), 29-31.

Pena, H. F. J., Gennari, S. M., Dubey, J. P., \& Su, C. (2008). Population structure and mouse-virulence of Toxoplasma gondii in Brazil. International Journal for Parasitology, 38(5), 561-569. doi: 10.1016/j. ijpara.2007.09.004

Pena, H. F. J., Soares, R. M., Amaku, M., Dubey, J. P., \& Gennari, S. M. (2006). Toxoplasma gondii infection in cats from São Paulo state, Brazil: seroprevalence, oocyst shedding, isolation in mice, and biologic and molecular characterization. Research in Veterinary Science, 81(1), 58-67. doi: 10.1016/j. rvsc.2005.09.007

Pereira, P. F., Barbosa, A. da S., Moura, A. P. P. de, Vasconcellos, M. L., Uchôa, C. M. A., Bastos, O. M. P., .. . Amendoeira, M. R. R. (2017). Gastrointestinal parasites in stray and shelter cats in the municipality of Rio de Janeiro, Brazil. Revista Brasileira de Parasitologia Veterinária, 26(3), 383-388. doi: 10.1590/s1984-29612017024

Robben, S. R., le Nobel, W. E., Döpfer, D., Hendrikx, W. M., Boersema, J. H., Fransen, F., \& Eysker, M. E. (2004). Infections with helminths and/or protozoa in cats in animal shelters in the Netherlands. Tijdschrift Voor Diergeneeskunde, 129(1), 2-6.

Robertson, I. D., Irwin, P. J., Lymbery, A. J., \& Thompson, R. C. A. (2000). The role of companion animals in the emergence of parasitic zoonoses. International Journal for Parasitology, 30, 1369-1377.

Ruffolo, B. B., Toledo, R. dos S., Martins, F. D. C., Bugni, F. M., Costa, L. da, Marana, E. R. M.,... Freire, R. L. (2016). Isolation and genotyping of Toxoplasma 
gondii in seronegative urban rats and presence of antibodies in communicating dogs in Brazil. Revista Do Instituto de Medicina Tropical de Sao Paulo, 58(28) 1-6. doi: 10.1590/S1678-9946201658028

Ruiz, A., \& Frenkel, J. K. (1980). Toxoplasma gondii in Costa Rican cats. The American Journal of Tropical Medicine and Hygiene, 29(6), 1150-1160.

Sabshin, S. J., Levy, J. K., Tupler, T., Tucker, S. J., Greiner, E. C., \& Leutenegger, C. M. (2012). Enteropathogens identified in cats entering a Florida animal shelter with normal feces or diarrhea. Journal of the American Veterinary Medical Association, 241(3), 331-337. doi: 10.2460/javma.241.3.331

Samico-Fernandes, E. F. T., Melo, R. P. B. de, Kim, P. de C. P., Almeida, J. C. de., Barros, L. D. de, Garcia, J. L., . . Mota, R. A. (2015). First report of genotype \#65 of Toxoplasma gondii in pigs. Parasitology Research, 114, 3927-3930. doi: 10.1007/s00436015-4664-z

Santin, M., Trout, J. M., Vecino, J. A. C., Dubey, J. P., \& Fayer, R. (2006). Cryptosporidium, Giardia and Enterocytozoon bieneusi in cats from Bogota (Colombia) and genotyping of isolates. Veterinary Parasitology, 141(3-4), 334-339. doi: 10.1016/j. vetpar.2006.06.004

Sergeant, E. S. G. (2017). Epitools epidemiological calculators. Ausvet Pty Ltd.

Serra, C. M. B., Uchôa, C. M. A., \& Coimbra, R. A. (2003). Exame parasitológico de fezes de gatos (Felis catus domesticus) domiciliados e errantes da Região Metropolitana do Rio de Janeiro, Brasil. Revista Da Sociedade Brasileira de Medicina Tropical, 36(3), 331-334.

Shwab, E. K., Zhu, X., Majumdar, D., Hilda, F. J., Gennari, S. M., Dubey, J. P., \& Su, C. (2014). Geographical patterns of Toxoplasma gondii genetic diversity revealed by multilocus PCRRFLP genotyping. Parasitology, 141, 453-461. doi: 10.1017/S0031182013001844
Su, C., Shwab, E. K., Zhou, P., Zhu, X. Q., \& Dubey, J. P. (2010). Moving towards an integrated approach to molecular detection and identification of Toxoplasma gondii. Parasitology, 137(1), 1-11. doi: 10.1017/ S0031182009991065

Su, C., Zhang, X., \& Dubey, J. P. (2006). Genotyping of Toxoplasma gondii by multilocus PCR-RFLP markers: A high resolution and simple method for identification of parasites. International Journal for Parasitology, 36(7), 841-848. doi: 10.1016/j. ijpara.2006.03.003

Willis, H. H. (1921). A Simple Levitation Method for the Detection of Hookworm Ova. Medical Journal of Australia, 2(18), 375-376.

Xiao, L., \& Fayer, R. (2008). Molecular characterisation of species and genotypes of Cryptosporidium and Giardia and assessment of zoonotic transmission. International Journal for Parasitology, 38, 12391255. doi: 10.1016/j.ijpara.2008.03.006

Xiao, L., Morgan, U. M. U., Limor, J., Escalante, A., Arrowood, M., Shulaw, W.,... Lal, A. A. (1999). Genetic diversity within Cryptosporidium parvum and related Cryptosporidium species. Applied and Environmental Microbiology, 65(8), 3386-3391.

Yang, R., Ying, J. L. J., Monis, P., \& Ryan, U. (2015). Molecular characterisation of Cryptosporidium and Giardia in cats (Felis catus) in Western Australia. Experimental Parasitology, 155, 13-18. doi: 10.1016/j.exppara.2015.05.001

Zahedi, A., Paparini, A., Jian, F., Robertson, I., \& Ryan, U. (2016). Public health significance of zoonotic Cryptosporidium species in wildlife: Critical insights into better drinking water management. International Journal for Parasitology: Parasites and Wildlife, 5(1), 88-109. doi: 10.1016/j.ijppaw.2015.12.001 